\section{References}

1 Pedersen J. The pregnant diabetic and her newborm. Copenhagen: Munksgaard, 1967.

2 Christy M, Green A, Christau B, Kromann H, Nerup J. Epidemiologic studies of insulindependent diabetes mellitus. Diabetes Care 1979;2:127-30.

3 Christau B, Mølbak AG. Incidence rates for type 1 (insulin-dependent) diabetes and insulin treated diabetes in age groups over 30 years. Diabetologia 1982;23:160.

4 Faber OK, Binder C. C-peptide response to glucagon. A test for the residual beta cell function in diabetes mellitus. Diabetes 1977;26:605-10.

5 Heding LG. Radioimmunological determination of human C-peptide in serum. Diabetologia 1975;11:541-8.

6 Trinder P. Determination of glucose in blood using glucose oxidase with an alternative oxygen acceptor. Ann Clin Biochem 1969;6:24-7.

$7 \mathrm{Kühl} \mathrm{C}$. Glucose metabolism during and after pregnancy in normal and gestational diabetic women. I. Influence of normal pregnancy on serum glucose and insulin concentration during basal fasting conditions and after a challenge with glucose. Acta Endocrinol 1975;79:709-19.

$8 \mathrm{Kühl} \mathrm{C,} \mathrm{Holst} \mathrm{JJ.} \mathrm{Plasma} \mathrm{glucagon} \mathrm{and} \mathrm{the} \mathrm{insulin-glucagon} \mathrm{ratio} \mathrm{in} \mathrm{gestational} \mathrm{diabetes.} \mathrm{Diabetes}$ 1976;25:16-23.

9 Natvig H. Nye hayde-vekttabeller for norske kvinner og menn. Landsforeningen for kosthold og helse. Oslo: Universitetsforlaget, 1956

10 Madsbad S, Krarup T, McNair P, et al. Practical clinical value of the C-peptide response to glucagon stimulation in the choice of treatment in diabetes mellitus. Acta Med Scand 1981;210:153-6.

11 Rubinstein $\mathrm{P}$, Walter $M$, Krassner J, et al. HLA antigens and islet cell antibodies in gestational diabetes. Hum Immunol 1981;3:271-5.
12 Rimoin DL, Rotter JI. The genetics of diabetes mellitus. In: Andreani D, Di Mario U, Federlin KF, Heding LG, eds. Immunology in diabetes. London, Edinburgh: Kimpton Medical Publications, 1984:45-62.

13 Christau B, Kromann H, Christy M, Andersen OO, Nerup J. Incidence of insulin-dependent diabetes mellitus (0-29 years at onset) in Denmark. Acta Med Scand 1979; suppl 624:54-60.

14 Gray RS, Duncan LJP, Clarke BF. Seasonal onset of insulin dependent diabetes in relation to sex and age onset. Diabetologia 1979;17:29-32.

15 D'Andrea JB, Wilson GL, Craighead JE. Effect of genetic obesity in mice on the induction of diabetes by encephalomyocarditis virus. Diabetes 1981;30:451-4.

16 Eizirik DL, Migliorini RH. Reduced diabetogenic effect of streptozotocin in rats previously adapted to a high-protein, carbohydrate-free diet. Diabetes 1984;33:383-8.

17 West DB, Seino Y, Woods SC, Porte D. Ventromedial hypothalamic lesions increase pancreatic sensitivity to streptozotocin in rats. Diabetes 1980;29:948-51.

18 Buschard K. The thymus-dependent immune system in the pathogenesis of type 1 (insulindependent) diabetes mellitus. Animal model and human studies. Dan Med Bull 1985;32:139-51.

19 Garsenstein M, Pollak VE, Kark RM. Systemic lupus erythematosus and pregnancy. $N$ Engl $\mathcal{f}$ Med 1962;267:165-9.

20 Persellin RH. The effect of pregnancy on rheumatoid arthritis. Bull Rheum Dis 1976;27:922-7.

21 Sridama V, Pacini F, Yang S-L, Moawad A, Reilly M, DeGrott LJ Decreased levels of helper T cells. A possible cause of immunodeficiency in pregnancy. N Engl I Med 1982;307:352-6.

22 Buschard K, Röpke C, Madsbad S, Mehlsen J, Sørensen TB, Rygaard J. Alterations of peripheral T-lymphocyte subpopulations in patients with insulin-dependent (type 1) diabetes mellitus. f Clin Lab Immunol 1983;10:127-31.

(Accepted 11 November 1986)

\title{
Prevalence of asthma and hay fever in England and Wales
}

\author{
D M FLEMING, D L CROMBIE
}

\begin{abstract}
The results concerned with the prevalence of asthma and hay fever in the large surveys of morbidity in general practice in 1970-1 and 1981-2 were compared. In data standardised for age the prevalence of asthma in men increased from 11.6 to 20.5 people consulting per 1000 population $(p<0.001)$ and in women from 8.8 to 15.9 per 1000 population $(p<0.001)$. Similar increases were also evident in data analysed from the 19 practices contributing to both surveys. The prevalence of asthma increased in each age group examined. Increases of similar magnitude were reported for hay fever-the prevalence in men increased from 10.8 to 19.8 people consulting per 1000 population $(p<0.001)$ and in women from 10.3 to 19.7 per 1000 population $(p<0.001)$ and occurred in all age groups. The prevalence of acute bronchitis was reduced significantly in the age group 5-14 and increased among the elderly. The prevalence of chronic bronchitis was reduced substantially in 1981-2.

The reported increased prevalence of both asthma and hay fever represented a real increase and was not accounted for by changes in diagnostic preference.. Only in the age group 5-14 was there any likelihood that some of the increased prevalence of asthma might have resulted from a reduction in the prevalence of acute bronchitis.
\end{abstract}

\section{Introduction}

The annual period prevalence of asthma reported in three large morbidity surveys in general practice increased from 8.5 people consulting per 1000 registered population in $1955-6^{1}$ to 10.2 in $1970-1^{2}$ and to $17 \cdot 8$ in $1981-2 .^{3}$ The corresponding prevalence of hay fever was $5 \cdot 1,10 \cdot 6$, and $19 \cdot 7$. Each of these surveys was based on a population of about 300000 and a nationwide distribution of

Birmingham Research Unit of the Royal College of General Practitioners, Harborne, Birmingham B17 9DB

D M FLEMING, MB, FRCGP, deputy director

D L CROMBIE, MD, FRCGP, director

Correspondence to: Dr Fleming. practices in which total recording of morbidity from every consultation was sustained over 12 months.

During recent years several reports, taken together, have suggested that the prevalence of asthma has increased. The sales of drugs for treating asthma increased consistently from 1975 to $1981 .{ }^{4}$ Rates of hospital discharge of men with asthma increased from $7 \cdot 0$ / 10000 in 1975 to 8.7 in 1978 and 12.3 in 1981 . Corresponding rates for women were $6 \cdot 7,8 \cdot 1$, and $10 \cdot 3$. In each year there was a distinct excess of men in the age group 0-14 years. ${ }^{5}$ Social security claims for absence from work owing to asthma doubled between 1968 and 1982.6

In 1960 there were 1188 deaths from asthma in England and Wales, and this figure increased to a maximum of 1927 in 1965 , returning to 1245 in 1970 . The increase and decline prompted much speculation about the possible role of aerosol inhalers as a contributory factor, and this matter never has been fully resolved. ${ }^{7}$ In a study of published national mortality statistics for England and Wales from 1974 to 1984 , in which account was taken of the impact of the ninth revision of the International Classification of Diseases in 1979, Burney concluded that mortality for asthma was increasing. ${ }^{8}$ The trend occurred during a period in which most doctors would accept that substantial advances had been made in the management of asthma.

The difficulties of defining asthma and of its epidemiological study are well known. ${ }^{910}$ Among these the preferences of doctors in their choice of diagnostic label may change, resulting in diagnostic transfer between the classificatory headings. Opinions on management vary considerably among both consultants ${ }^{11}$ and general practitioners. ${ }^{12}$ Among children underrecognition of the condition leads to avoidable suffering. ${ }^{13}$ Response to histamine challenge has been used as a diagnostic test, but this is not uniformly reliable. ${ }^{14}$

In the study reported here data about asthma and related illnesses during 1981-2 were compared with data obtained in a similar survey about 10 years before to try to discover if the prevalence of asthma and hay fever is increasing.

\section{Methods}

Data for this study were obtained during the national morbidity surveys in general practice in $1970-1^{2}$ and $1981-2{ }^{3}$ Figure 1 shows the geographical distribution of the participating practices. Data available in the material 


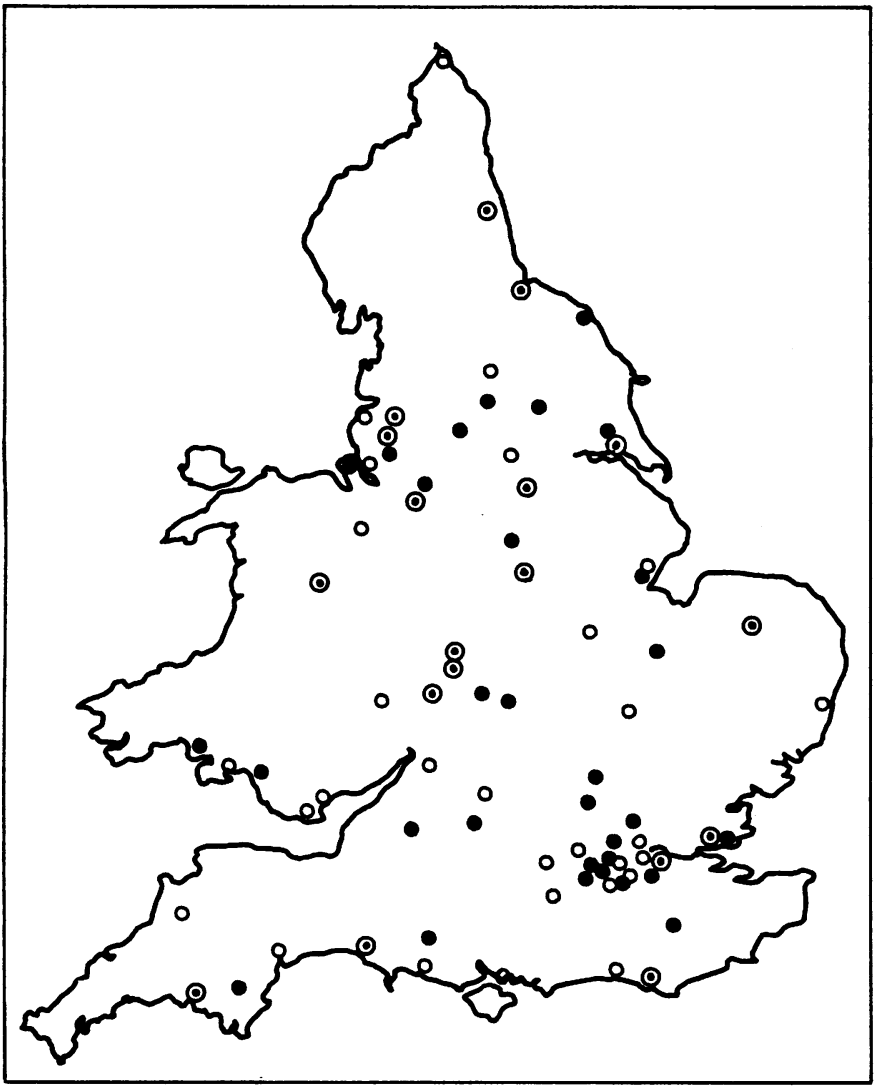

FIG 1 -Locations of practices participating in morbidity surveys. $\quad=1970-1$. $O=1981-2 . O=1970-1$ and $1981-2$.

included the number of people suffering from specified conditions, the number of episodes of illness experienced, and the number of consultations undertaken during the year of the survey. The study reported here is concerned chiefly with people consulting their doctors about asthma, hay fever (including allergic rhinitis), acute bronchitis (including bronchiolitis), and chronic bronchitis. The allocation of an illness to a heading of the classification was made at the time of consultation. Further information about the survey method is available in the publications already mentioned.

The prevalence of asthma and the other illnesses in each survey were examined for each sex separately and by age. We evaluated the significance of the differences with the $\chi^{2}$ test. Nineteen practices participated in both surveys and for these prevalences were standardised for age by the direct method to the national population structure in 1981. Differences between
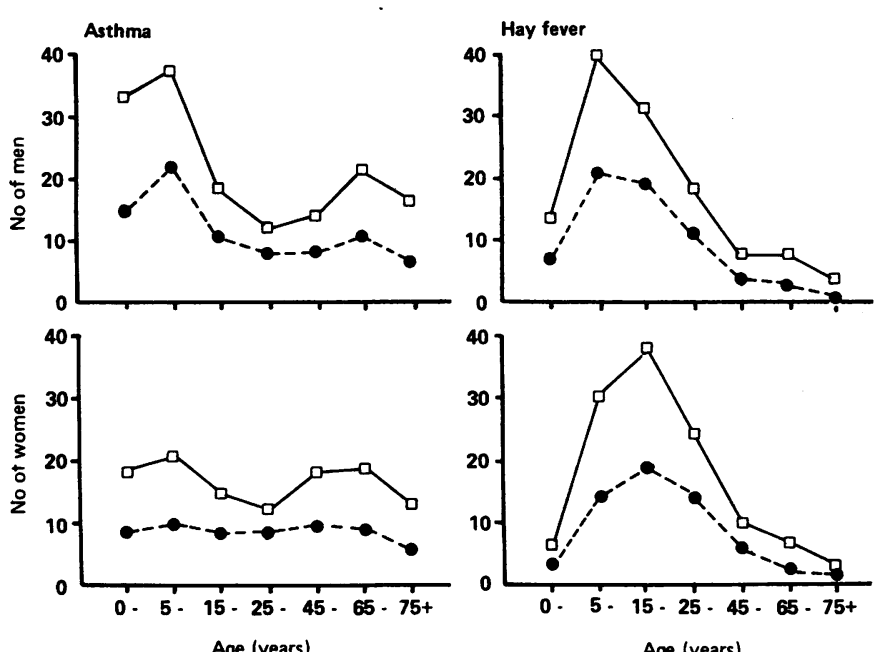

FIG 2-No of people in all practices consulting for asthma and hay fever per 1000 population by age and sex. $\odot=1970 . \square=1981$. the standardised practice prevalences of the two surveys were evaluated by Cochran's method, ${ }^{15}$ which is an extension of the $\chi^{2}$ test, weighting for the differences occurring in the constituent practice populations.

\section{Results}

Figure 2 shows the prevalence, obtained from the two surveys, of asthma and hay fever by sex and by age. In both surveys asthma was more prevalent $\Phi$ among men, largely because of a roughly twofold excess of boys. The TI differences between the prevalences in 1981 and 1970 were highly significant $\frac{?}{\text {. }}$ $(\mathrm{p}<0.001)$, with increases seen in all age groups and in both sexes. The $\vec{F}$ prevalence of hay fever in males was at its maximum in the age group 5-14 in $\stackrel{9}{+}$ both surveys, whereas for women the maximum prevalence occurred in the $\bar{C}$ age group 15-24. The prevalence was also higher in boys aged 0-4. The 흘 general pattern of results in men, however, was broadly similar to that in women in each of the surveys. There were highly significant increases $\overrightarrow{\mathbb{Q}}$ $(p<0.001)$ between the surveys in both sexes and for all age groups.
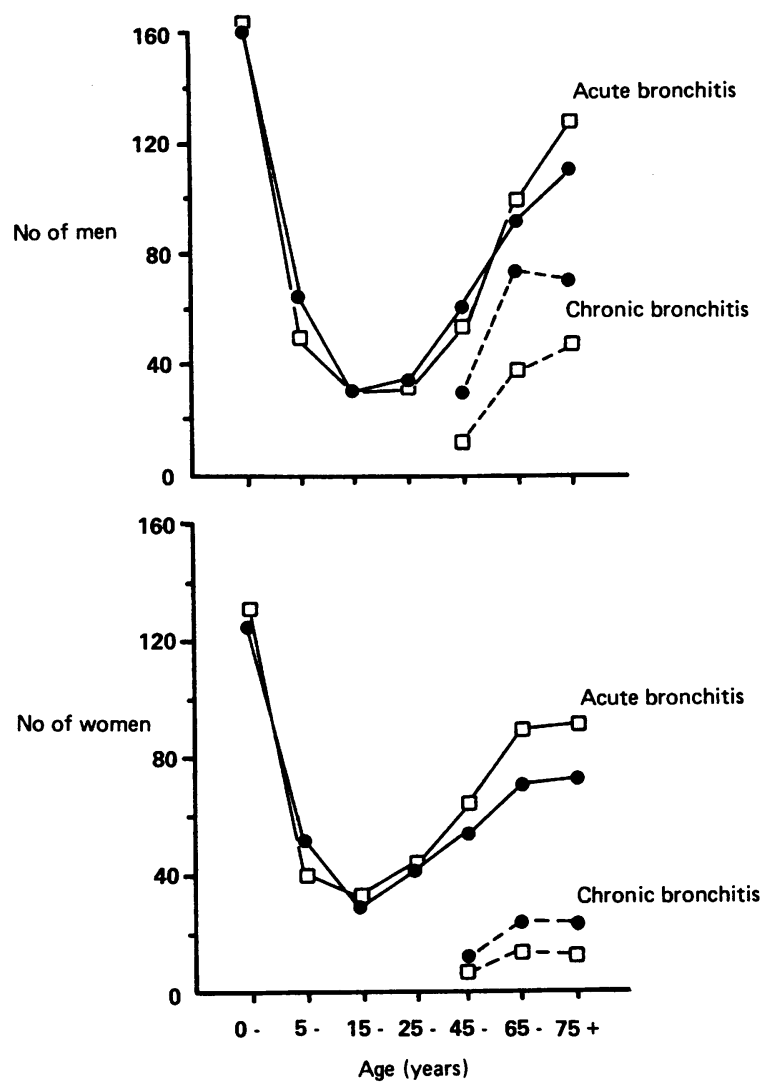

FIG 3-No of people in all practices consulting for acute bronchitis and chronic bronchitis per 1000 population by age and sex. $\Theta=1970$. $\square=1981$.

Overall the prevalence of acute bronchitis was similar in both surveys, but there were differences in the groups divided by age and sex (fig 3). The $\mathrm{O}$ prevalence in men increased significantly only in the age group 75 and over, $\mathrm{\omega}$ whereas in women the prevalence increased in the age groups 45-64, 65-74, and 75 and over. The prevalence decreased significantly in males aged 5-14, 25-44, and 45-64, whereas in women it decreased only in the age group 5-14. The prevalence among children aged 0-4 was similar in both surveys. In the age groups 5-14, 65-74, and 75 and over the prevalence in males was about $25 \%$ greater than that in women in both surveys. For chronic bronchitis there was an approximate twofold difference between the sexes and highly $\underset{\mathbb{D}}{\mathrm{D}}$ significant reductions in the prevalence in 1981 compared with that in 1970 .

Table I summarises the practice data standardised by age for the $19 \stackrel{\square}{\perp}$ practices that participated in both surveys and for each of the diseases. The differences between 1970 and 1981 in the prevalence of both asthma and hay fever (increased) and also of chronic bronchitis (decreased) were substantial $\frac{0}{0}$ and were highly significant. A highly significant decrease in the prevalence of acute bronchitis occurred in men, but the prevalence in women $\overline{0}$ increased significantly. Four of the 19 practices reported a significantly 
increased prevalence in men ( $\chi^{2}$ test on data from people consulting), and 10 practices reported decreases. For women there were five and four practices, respectively.

About $90 \%$ of patients consulting about any of the four conditions studied were recorded in only one of these diagnostic categories (table II). This proportion was similar in each of three age groups examined separately $(0.4$, $5-44$, and 45 and over). The proportion of patients with hay fever and acute bronchitis (about $85 \%$ ) was similar in both surveys, notwithstanding the significant decrease in women because of the very large number of patients in the study. In 1970, 942 men were diagnosed as suffering exclusively from asthma compared with 1863 in 1981; for women the numbers were 754 in 1970 and 1623 in 1981 . Not only were significantly more people diagnosed as suffering exclusively from asthma but the proportions of both men and women so diagnosed were significantly greater in 1981 than in 1970 $(p<0.001)$. In 1970, 545 men were reported as having asthma and acute bronchitis (33\% of all patients with asthma) compared with $723(25 \%)$ in $1981(\mathrm{p}<0.001)$. The corresponding values for women were 432 in 1970 $(32 \%)$ and 682 in $1981(27 \%)$. These trends, showing small increases in the proportion of people diagnosed as suffering exclusively from asthma and small decreases in the proportion who also had acute bronchitis, were evident on separate examination of the age groups $0-4,5-44$, and 45 and over. The proportion of men with asthma who also had hay fever increased from $7 \%$ to $12 \%$ and the proportion of women from $8 \%$ to $10 \%$. There were small but significant reductions in the proportions diagnosed as suffering exclusively from chronic bronchitis.

The total number of referrals from general practice to hospital based care reported in these surveys was 186 in 1970 and 292 in 1981 (not including self referrals by patients). The increase was virtually confined to referrals requiring emergency admission-75 in 1970 and 160 in 1981. The proportion of patients consulting about asthma and referred to outpatient

TABLE I-Prevalence of asthma, hay fever, acute bronchitis, and chronic bronchitis standardised for age/1000 population

\begin{tabular}{|c|c|c|}
\hline \multirow[b]{2}{*}{ Condition } & Men & Women \\
\hline & 1970 & 1970 \\
\hline $\begin{array}{l}\text { Mean from total survey } \\
\text { Mean from } 19 \text { practices } \\
\text { Weighted mean (SE) difference }\end{array}$ & $\begin{array}{cc}11 \cdot 6 & 20 \cdot 5 \\
11 \cdot 2 & 18 \cdot 4 \\
7 \cdot 26(0 \cdot 77)\end{array}$ & $\begin{array}{ll}8.8 & 15.9 \\
8.0 & 15 \cdot 8 \\
7 \cdot 54(0.66)\end{array}$ \\
\hline $\begin{array}{l}\text { Mean from total survey } \\
\text { Mean from } 19 \text { practices } \\
\text { Weighted mean (SE) difference }\end{array}$ & 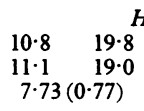 & $\begin{array}{ll}10.3 & 19 \cdot 7 \\
9 \cdot 6 & 19 \cdot 1 \\
9.47(0.73)\end{array}$ \\
\hline $\begin{array}{l}\text { Mean from total survey } \\
\text { Mean from } 19 \text { practices } \\
\text { Weighted mean (SE) difference }\end{array}$ & $\begin{array}{lr} & \text { Acu } \\
64 \cdot 6 & 62 \cdot 2 \\
64 \cdot 1 & 59 \cdot 2 \\
-5 \cdot 27 & (1 \cdot 52)\end{array}$ & $\begin{array}{ll}\text { hitis } & \\
53.4 & 58.3 \\
52 \cdot 2 & 55.0 \\
3.54^{\star} & (1 \cdot 36)\end{array}$ \\
\hline $\begin{array}{l}\text { Mean from total survey } \\
\text { Mean from } 19 \text { practices } \\
\text { Weighted mean (SE) difference }\end{array}$ & $\begin{array}{cc} & \text { Chron } \\
19.5 & 9 \cdot 7 \\
17.4 & 11 \cdot 1 \\
-6.07 & (0.75)\end{array}$ & $\begin{array}{lc}\text { chitis } & \\
7.6 & 4.0 \\
5.8 & 4.2 \\
-1.66 & (0.43)\end{array}$ \\
\hline
\end{tabular}

* All differences were very highly significant $(p<0.001)$ except for acute bronchitis in women $(\mathbf{p}<0.01)$.

TABLE II-Patients in all practices consulting classified by diagnosis and sex and number (\%) in whom only one condition was diagnosed

\begin{tabular}{|c|c|c|c|c|}
\hline & \multicolumn{2}{|c|}{ Patients consulting } & \multicolumn{2}{|c|}{$\begin{array}{l}\text { No (\%) in whom only one } \\
\text { condition was diagnosed }\end{array}$} \\
\hline & 1970 & 1981 & 1970 & 1981 \\
\hline $\begin{array}{l}\text { Asthma: } \\
\text { Men } \\
\text { Women }\end{array}$ & $\begin{array}{l}1647 \\
1346\end{array}$ & $\begin{array}{l}2850 \\
2560\end{array}$ & $\begin{array}{l}942(57) \\
754(56)\end{array}$ & $\begin{array}{l}1863(65)^{\star \star \star} \\
1623(63)^{\star \star \star \star}\end{array}$ \\
\hline $\begin{array}{l}\text { Hay fever: } \\
\text { Men } \\
\text { Women }\end{array}$ & $\begin{array}{l}1526 \\
1556\end{array}$ & $\begin{array}{l}2888 \\
3179\end{array}$ & $\begin{array}{l}1278(84) \\
1320(85)\end{array}$ & $\begin{array}{l}2387(83) \\
2680(84)\end{array}$ \\
\hline $\begin{array}{l}\text { Acute bronch } \\
\text { Men } \\
\text { Women }\end{array}$ & $\begin{array}{l}8659 \\
8246\end{array}$ & $\begin{array}{l}8490 \\
9409\end{array}$ & $\begin{array}{l}7404(86) \\
7400(90)\end{array}$ & $\begin{array}{l}7297(86) \\
8318(88)^{\star \star}\end{array}$ \\
\hline $\begin{array}{l}\text { Chronic bronc } \\
\text { Men } \\
\text { Women }\end{array}$ & $\begin{array}{l}2233 \\
1127\end{array}$ & $\begin{array}{r}1188 \\
646\end{array}$ & $\begin{array}{r}1498(67) \\
713(63)\end{array}$ & $\begin{array}{l}746(63)^{\star} \\
370(57)^{\star \star}\end{array}$ \\
\hline $\begin{array}{l}\text { Total } \\
\text { Men } \\
\text { Women }\end{array}$ & $\begin{array}{l}12539 \\
11197\end{array}$ & $\begin{array}{l}13801 \\
14340\end{array}$ & $\begin{array}{l}11122(89) \\
10187(91)\end{array}$ & $\begin{array}{l}12263(89) \\
12991(91)\end{array}$ \\
\hline
\end{tabular}

${ }^{\star} \mathrm{p}<0.05,{ }^{\star \star} \mathrm{p}<0.01,{ }^{\star \star} \mathrm{p}<0.001\left(\chi^{2}\right.$ test $)$. clinics showed a reduction between 1970 and 1981, while the proportion referred for admission to hospital increased.

The numbers of episodes of asthma and consultations for asthma reported in the 1981 survey exceeded those reported in 1970 (table III), but when expressed as mean rates per person consulting both rates decreased slightly.

\begin{tabular}{|c|c|c|c|c|}
\hline & \multicolumn{2}{|c|}{ Men } & \multicolumn{2}{|c|}{ Women } \\
\hline & 1970 & 1981 & 1970 & 1981 \\
\hline $\begin{array}{l}\text { No per } 1000 \text { population: } \\
\text { Patients consulting } \\
\text { Episodes } \\
\text { Consultations }\end{array}$ & $\begin{array}{l}11 \cdot 7 \\
15 \cdot 5 \\
37 \cdot 9\end{array}$ & $\begin{array}{l}20 \cdot 0 \\
23 \cdot 9 \\
52 \cdot 3\end{array}$ & $\begin{array}{r}8 \cdot 9 \\
11 \cdot 4 \\
31 \cdot 0\end{array}$ & $\begin{array}{l}15 \cdot 9 \\
19 \cdot 2 \\
44 \cdot 9\end{array}$ \\
\hline $\begin{array}{l}\text { No per person consulting: } \\
\text { Episodes } \\
\text { Consultations }\end{array}$ & $\begin{array}{l}1.32 \\
3 \cdot 24\end{array}$ & $\begin{array}{l}1.20 \\
2.62\end{array}$ & $\begin{array}{l}1 \cdot 28 \\
3 \cdot 48\end{array}$ & $\begin{array}{l}1 \cdot 21 \\
2 \cdot 82\end{array}$ \\
\hline
\end{tabular}

\section{Discussion}

The comparisons examined in this paper are based on patient consulting rates. Much of the research work using hospital statistics of admission and discharges is of limited epidemiological value because it is based on events and not people. One person may experience several events. Using samples based on events rather than people makes procedures for linking information about one illness with another much more difficult. In the morbidity surveys that provided the material for this study person specific data were analysed showing the linkage between conditions. By collecting comprehensive data of this type on a total defined population we have been able to assess the effects of diagnostic transfer and multiple diagnoses in one person. It should also be recognised that the comparison uses a large database with a population that is representative of the national population structure by age and $\operatorname{sex}^{3}$ and that included more than 5000 patients with asthma in the 1981 survey.

The increased prevalence of hay fever in 1981 compared with 1970 indicates at the very least that more people are resorting to treatment. The heading of hay fever in the disease classification includes allergic rhinitis, and sufferers in either survey had little opportunity to be assigned to any alternative. Treatment did improve during the decade, and the response to treatment may have been used as a diagnostic test, thus bringing more patients into this diagnostic category by the time of the 1981 survey. Against this, however, the prevalence of hay fever had doubled between the times of the first and second morbidity surveys before any great advances in treatment had been realised. The continuing trend, the magnitude of the increase, its uniformity in both sexes and all age groups, the related increase in the prevalence of asthma, and the wide consensus across all practices all support the idea that it represents true increased prevalence.

The apparent increased prevalence of asthma is more difficult to interpret. The broad perspective of asthma has not changed, its high prevalence and male sex bias in children being features of other surveys. ${ }^{16} 17$ Detailed comparisons of the results from different surveys are not possible because of the different methods used. Our study is based on a comparison of annual period prevalence determined by the need to consult and the diagnosis made by the doctor consulted. Community surveys use other methods and generally quote cumulative prevalence. The most difficult problem in interpreting data about asthma concerns the change in diagnostic preference over time. Is the condition that was called acute bronchitis in 1970 now called asthma? In a regionally based study of children admitted to hospital with asthma from 1970 to 1978 Anderson et al concluded that the increase in the number of patients admitted to hospital was not attributable to changes in diagnostic fashion..$^{18}$ Khot et al reached the same conclusion. ${ }^{19}$ This study, showing a considerably increased prevalence of asthma during a 
period in which no overall change in the prevalence of acute bronchitis occurred suggests that there was no overall change in diagnostic practice between the surveys. Two observations, however, need further consideration: the reduced prevalence of acute bronchitis in children of both sexes aged 5-14 and the reduced prevalence of chronic bronchitis.

In an overview of the 1981 survey results for total morbidity compared with those for 1970 consultation rates increased among women in all age groups and among all men except those aged 15-44 and 45-64. The data on upper respiratory tract infections (coryza and so on) follow the same general trends, with particularly large increases in prevalence among children of both sexes aged 0-4 and 5-14. The bias towards boys seen in the statistics for asthma was not present in those for upper respiratory infections, though a male bias was present in the results for acute bronchitis and was of comparable magnitude in both surveys. Such a bias suggests misdiagnosis and confirms suspicions that confusion over diagnosis exists, especially in this age group. These data, however, suggest that the confusion in 1981 was hardly different from that in 1970 . Though some cases diagnosed as acute bronchitis in $\mathbf{1 9 7 0}$ may have been diagnosed as asthma in 1981, we suspect that more would have been diagnosed as infections of the upper respiratory tract.

Among the elderly chronic bronchitis may cause confusion. The reduced prevalence of chronic bronchitis accords with our own clinical experience, in which recently we have seen fewer patients crippled by irreversible airways obstruction than we did 10 or 15 years ago. We accept that this is a real decrease. The number of elderly patients with acute bronchitis has increased as well as the number of patients with asthma and may hide some of the true increase in prevalence of asthma. We think that it is unlikely that any change in diagnostic preference occurring during the period between the surveys could account for any substantial part of the increased prevalence reported.

Some patients with asthma also experienced hay fever or acute bronchitis in the same year. It is conceivable that during the period between the surveys a change in diagnostic practice may have resulted in more patients being recorded in multiple diagnostic categories, thereby spuriously suggesting an increased prevalence. The data presented here, however, show that not to be the case. Multiple diagnoses were made during both surveys and in both sexes in about $10 \%$ of cases, suggesting a consistency in the diagnostic process. The number and proportion of patients diagnosed as suffering exclusively from asthma increased, whereas the number and proportion of those with acute bronchitis were virtually the same. Thus among patients diagnosed as suffering exclusively from one disease there is no evidence of a change in diagnostic preference during the period between the surveys.

The significant change in the prevalence of acute bronchitis in men aged 45-64 may indicate a declining prevalence of acute bronchitis in middle aged men, but it is more likely to reflect a changing pattern of consultation resulting from the gradual relaxation of requirements for sickness certificates during recent years. The contrasting increase in women accords with a general increase seen both in patient consulting rates and mean consultation rates, which extend across the entire range of morbidity.

Data from the Hospital In-Patient Enquiry in 1981 provided an estimate of 11.3 hospital discharges $/ 10000$ population-a figure that in any case must exceed an estimate based exclusively on patients discharged-whereas the prevalence of asthma reported here for 1981 was $178 / 10000$. Whatever changes have taken place in the policy of admission to hospital and in arrangements for self referral they have little effect on the statistics for prevalence derived from a total population study in general practice. From this study, however, it can be seen that more patients were referred to hospital in 1981 than in 1970 and that this increase was confined to referrals for admission. Even so, referral is comparatively rare, and any appraisal of the prevalence of asthma must be made in a population based study.

Both asthma and hay fever are highly variable conditions and are at least partly influenced by environmental factors. The years 1970 and 1981 may therefore represent "good" and "bad" years, respectively, for these conditions. In a similar national morbidity survey available for 1971-2 the prevalence of asthma and hay fevero was similar to that in 1970-1. From data from the weekly returns service of the Royal College of General Practitioners ${ }^{20}$ (a group of practices keeping records that overlap considerably with those included in the national morbidity surveys) Ayres showed that the prevalence of both conditions was similar in the years immediately before and after the 1981-2 survey reported here. ${ }^{6}$

The analysis within the practices is especially important because it minimises the effect of confounding variables. The practices are ing the same place; topographical, meteorological, and demographic. characteristics scarcely change within a decade. A substantia proportion of the population registered with the practice would have been present at both surveys. Most doctors contributed to both, though there were some changes. Important local changes wilif have occurred: some factories will have closed, in other region unemployment may have increased, weather conditions in the critical hay fever season may have been very different in the two years of the survey, and the prevalence of viral disorders tha $\vec{b}$ predispose a patient to acute bronchitis may have varied widely These local changes, though accounting for variation in individuad, practices from the general pattern of results, are lost in the analysis of data from 19 widely distributed practices and in the data from a $\overline{\mathbb{B}}$. the surveys. In this regard the increases in the prevalence of asthmid and hay fever were remarkably uniform whereas changes irf the prevalence of acute bronchitis in individual practices weres haphazard, with both substantial increases and decreases among the 19 practices.

We conclude from this analysis that the true prevalence of botko asthma and hay fever has increased. The increases have been of 9 similar magnitude, with uniform effects in both sex and age groups $\omega_{2}$ but each of these illnesses remains different with regard to the age and sex distribution of the sufferers. Many people have expresse the opinion that the prevalence of both conditions is increasing, buw few so forcibly as Morrison-Smith who, reflecting on his lifetime experience as a chest doctor, noticed that when he was aged 20 ne्ठ doctor recognised the condition of hay fever from which he wag suffering and that patients diagnosed as suffering from asthmo were few and far between. ${ }^{21}$ More recently there has been welp documented evidence of increased prevalence in New Zealand an $\Phi$ other parts of Australasia. ${ }^{4}$ In their analysis of trends in the hospitad care of childhood asthma Anderson et al identified the need to see epidemiological evidence to distinguish between an increase in the number of people who have asthma and an increased frequency oo asthmatic episodes. ${ }^{18}$ They also lamented the paucity of data about non-fatal conditions such as asthma. The value of the generdif practice survey based on a large population is easily overlooked:Although this study was largely concerned with the number of patients consulting, small reductions in the mean number of episodes per person consulting about asthma and in the meat number of consultations per peson consulting were also seen. Such. reductions may be partly explained by increased recruitment $0 \$$ patients who are less severely ill or by improvements in managemen by the general practitioners concerned.

The increased prevalence of asthma and hay fever occurred in aht age groups and hence is not likely to relate to some change in genetic predisposition. Increases were evident in widely scattered practiceso suggesting a national rather than local explanation. We can onl. speculate that our response mechanism to airborne irritants is bein modified gradually by dietary factors, by disease processes, or by other factors that we do not understand; alternatively, contamina tion of the environment by potential irritants (new or existing) mat have increased. The patterns of increase for both asthma and ha fever are similar, suggesting a common explanatory factor.

National morbidity surveys require collaboration among the Office Population Censuses and Surveys, the Department of Health and Socid Security, and the Royal College of General Practitioners. From the Birmingham research unit of the Royal College of General Practitioners we acknowledge the good will that exists in the prosecution of these surveys Most important, however, is the discipline required for recording the information in the participating practices, and we are grateful to the participating doctors and the research secretaries. Most of the analytical 
work and the statistical interpretation have been undertaken by Mrs C A Norbury (Birmingham research unit) and Dr K W Cross (department of social medicine, Birmingham University), and we are especially grateful to them. We also thank the Office of Population Censuses and Surveys for the subsidiary analysis of the original material to provide the data for table II.

\section{References}

1 Logan WDP, Cushion AA. Morbidity statistics from general practice. Studies on medical and population subjects No 14. London: HMSO, 1958.

2 Office of Population Censuses and Surveys, Royal College of General Practitioners, and Department of Health and Social Security. Morbidity statistics from general practice. Second national study 1970-71. Studies on medical and population subjects No 26. London: HMSO, 1974. 3 Office of Population Censuses and Surveys, Royal College of General Practitioners, and Department of Health and Social Security. Morbidity statistics from general practice. Third national study 1981-82. London: HMSO, 1986. (Series MB5 No 1.)

4 Keating G, Mitchell EA, Jackson R, Beaglehole R, Rea $H$. Trends in sales of drugs for asthma in New Zealand, Australia, and the United Kingdom, 1975-81. Br Med f 1984;289:348-51.

5 Office of Population Censuses and Surveys. Hospital in-patient enquiry. London: HMSO, 1975 , 1978, 1981. (Series MB4.)

6 Ayres JG. Trends in asthma and hay fever in general practice in the United Kingdom 1976-83. Thorax 1986;41:111-6.

7 Cushley MJ, Tattersfield AE. Sudden death in asthma: discussion paper. $\mathcal{F} R$ Soc Med 1983;76:662-6.
8 Burney PGJ. Asthma mortality in England and Wales: evidence for a further increase, 1974-84. Lancet 1986;ii:323-6.

9 Ciba Foundation Study Group. Identification of asthma. Edinburgh and London: Churchill Livingstone, 1971 .

10 Gregg I. Epidemiological aspects. In: Clark TJH, Godfrey S, eds. Asthma. 2nd ed. London: Chapman and Hall, 1983.

11 Henry RL, Milner AD. Specialist approach to childhood asthma: does it exist? $\mathrm{Br}$ Med $\mathcal{J}$ 1983;287:260-1.

12 Marks RE, Hillier VF. General practitioners' views on asthma in childhood. Br Med $\mathcal{J}$ 1983;287:949-51.

13 Speight ANP, Lee DA, Hey EN. Underdiagnosis and undertreatment of asthma in childhood. BrMed F 1983;286:1253-6.

14 Lee DA, Winslow NR, Speight ANP, Hey EN. Prevalence and spectrum of asthma in childhood. BrMed F 1983;286:1256-8.

15 Cochran WG. Some methods for strengthening the common $\chi^{2}$ tests. Biometrics 1954;10:417-51. 16 Peckham C, Butler N. A national study of asthma in childhood. I Epidemiol Community Health 1978;32:79-85.

17 Kaplan BA, Mascie-Taylor CGN. Biosocial factors in the epidemiology of childhood asthma in a British national sample. F Epidemiol Community Health 1985;39:152-6.

18 Anderson HR, Bailey P, West S. Trends in the care of acute childhood asthma 1970-8: a regional study. BrMed F 1980;281:1191-4.

19 Khot A, Burn R, Evans N, Lenney C, Lenney W. Seasonal variation and time trends in childhood asthma in England and Wales 1975-81. BrMed $\mathcal{J}$ 1984;289:235-7.

20 Fleming DM, Crombie DL. The incidence of common infectious diseases: the weekly returns service of the Royal College of General Practitioners. Health Trends 1985;17:13-6.

21 Morrison-Smith J. "In my own time." Asthma. Br Med J 1979;ii:118-9.

(Accepted 25 November 1986)

\title{
Atrial fibrillation precipitated by acute hypovolaemia
}

\author{
J D EDWARDS, R G WILKINS
}

\section{Abstract}

Six patients with varying degrees of acute cardiorespiratory failure were seen. All patients deteriorated noticeably when rapid atrial fibrillation developed. In all patients intravenous digitalis failed to slow the ventricular response, and in three patients misguided attempts at electrical cardioversion failed. Haemodynamic monitoring showed a normal or low pulmonary artery occlusion pressure in all patients. Controlled expansion of plasma volume was associated with an immediate slowing of the heart rate in all patients, and the heart rate in all patients returned to sinus rhythm within $\mathbf{3 0}$ minutes of transfusion.

It is suggested that hypovolaemia in critically ill patients may contribute to the development of atrial fibrillation.

\section{Introduction}

Atrial fibrillation is a recognised complication of acute non-cardiac illness $^{1}$ and in normovolaemic patients with underlying left ventricular dysfunction usually results in dangerous falls in cardiac output and perfusion pressure associated with a deterioration in gas exchange due to rises in pulmonary artery occlusion pressure. ${ }^{2}$ It has been suggested that hypovolaemia may precipitate atrial fibrillation in a critically ill patient and should be excluded, ${ }^{3}$ but this has never been documented adequately. Over two years we saw six patients who developed rapid atrial fibrillation in association with severe hypovolaemia which was shown by invasive monitoring.

\footnotetext{
Intensive Care Unit, Withington Hospital, West Didsbury, Manchester M20 8LR

J D EDWARDS, MRCP, consultant

R G WIL KINS, FFARCS, consultant

Correspondence to: Dr Edwards.
}

\section{Patients and methods}

Case 1-A 56 year old man underwent emergency repair of a leaking aortic aneurysm. Postoperatively his central venous pressure was maintained at $10 \mathrm{~cm} \mathrm{H}_{2} \mathrm{O}$ from the sternal angle. He remained oliguric (urine output $10-15 \mathrm{ml} / \mathrm{h}$ ) and hypotensive (systolic blood pressure $100-105 \mathrm{~mm} \mathrm{Hg}$ ). Thirty six hours after surgery he suddenly became breathless, and his systolic blood pressure fell to $60 \mathrm{~mm} \mathrm{Hg}$. He was found to be suffering from rapid atrial fibrillation. Two attempts at cardioversion with direct current shocks of 150 and 400 joules failed. He subsequently developed adult respiratory distress syndrome, which necessitated mechanical ventilation for 10 days.

Case 2-A 48 year old man was admitted suffering from alcohol withdrawal, as evidenced by delirium tremens. On the day of admission he became progressively breathless. Fluid replacement seemed adequate (2.4 litres of crystalloid over seven hours), but he developed sudden circulatory collapse, worsening respiratory distress, and rapid atrial fibrillation. This did not respond to two attempts at cardioversion (200 and 400 joules, respectively). After resuscitation he was found to have bilateral bronchopneumonia.

Case 3-A 64 year old woman developed circulatory collapse and was found to be suffering from rapid atrial fibrillation 14 hours after a carotid endarterectomy. Three attempts at cardioversion (100, 200, and 400 joules) failed, and she developed progressive respiratory distress. After resuscitation she was found to have a staphylococcal septicaemia.

Case 4-Two days after surgery for a perforated duodenal ulcer a 62 year old man developed progressive hypotension (systolic blood pressure falling from 110 to $75 \mathrm{~mm} \mathrm{Hg}$ over six hours). Soon afterwards he became breathless, and the rhythm changed to atrial fibrillation. His respiratory distress was thought, on clinical and radiological grounds, to be due to left ventricular failure. He was subsequently shown to have septicaemia due to Escherichia coli and adult respiratory distress syndrome.

Case 5-A 46 year old woman was admitted with dyspnoea, which had developed over 24 hours. On examination she was found to be hypotensive and suffering from rapid atrial fibrillation. Chest radiography showed infiltration in the left lower lobe, which later became generalised. After resuscitation she was found to have pneumococcal pneumonia and septicaemia.

Case 6-A 64 year old man became hypotensive and breathless after a viral type illness that had lasted for $\mathbf{4 8}$ hours. On admission he was hypotensive and in extreme respiratory distress. He was suffering from rapid atrial fibrillation and had bilateral crepitations. Though he was initially thought to be suffering from left ventricular failure, haemodynamic studies and 